\title{
Inhibitory monoclonal antibodies against mouse proteases raised in gene-deficient mice block proteolytic functions
} in vivo

\author{
Ida K. Lund ${ }^{1,2}$, Morten G. Rasch ${ }^{1,2,3}$, Signe Ingvarsen ${ }^{1,2}$, Jesper Pass ${ }^{1,2,3}$, Daniel H. Madsen ${ }^{1,2,4}$, \\ Lars H. Engelholm ${ }^{1,2}$, Niels Behrendt ${ }^{1,2}$ and Gunilla Høyer-Hansen ${ }^{1,2}$ * \\ 1 The Finsen Laboratory, Copenhagen University Hospital, Copenhagen, Denmark \\ ${ }^{2}$ Biotech Research and Innovation Centre, Copenhagen University, Copenhagen, Denmark \\ ${ }^{3}$ Antibody Technology, Biopharmaceutical Research Unit, Novo Nordisk A/S, Målov, Denmark \\ ${ }^{4}$ Proteases and Tissue Remodeling Section, Oral and Pharyngeal Cancer Branch, National Institute of Dental and Craniofacial Research, \\ National Institutes of Health, Bethesda, MD, USA
}

\section{Edited by:}

Agnès Noël, University of Liege,

Belgium

Reviewed by:

David Smadja, Paris Descartes University, France

Hervé Emonard, Centre National de la

Recherche Scientifique, France

\section{*Correspondence:}

Gunilla Hoyer-Hansen, The Finsen Laboratory, Copenhagen University Hospital, Copenhagen Biocenter, Ole Maaløes Vej 5, DK-2200 Copenhagen N, Denmark.

e-mail: gunilla@finsenlab.dk
Identification of targets for cancer therapy requires the understanding of the in vivo roles of proteins, which can be derived from studies using gene-targeted mice. An alternative strategy is the administration of inhibitory monoclonal antibodies (mAbs), causing acute disruption of the target protein function(s). This approach has the advantage of being a model for therapeutic targeting. mAbs for use in mouse models can be obtained through immunization of gene-deficient mice with the autologous protein. Such mAbs react with both species-specific epitopes and epitopes conserved between species. mAbs against proteins involved in extracellular proteolysis, including plasminogen activators urokinase plasminogen activator (UPA), tissue-type plasminogen activator (tPA), their inhibitor PAI-1, the UPA receptor (UPAR), two matrix metalloproteinases (MMP9 and MMP14), as well as the collagen internalization receptor UPARAP, have been developed. The inhibitory mAbs against UPA and UPAR block plasminogen activation and thereby hepatic fibrinolysis in vivo. Wound healing, another plasmin-dependent process, is delayed by an inhibitory mAb against uPA in the adult mouse. Thromboembolism can be inhibited by anti-PAl-1 mAbs in vivo. In conclusion, function-blocking mAbs are well-suited for targeted therapy in mouse models of different diseases, including cancer.

Keywords: mouse monoclonal antibodies, extracellular proteolysis, collagen internalization, in vivo models, plasminogen activation

\section{INTRODUCTION}

Most of our understanding of the in vivo roles of extracellular proteases, their cellular receptors and inhibitors is derived from studies using gene-targeted mice. The phenotype of a genedeficient mouse can, however, be influenced by redundancy, when the function of the protein encoded for by the inactivated gene is compensated due to overlapping functions between proteins (Page-McCaw et al., 2007; Stevens et al., 2012). Identification of the in vivo function of a protease/receptor in an adult mouse can be obtained by administration of inhibitory monoclonal antibodies (mAbs), causing acute disruption of the target protein function(s), further offering the advantage of directly serving as a model for therapeutic targeting. In order to avoid immunogenicity effects in mice, the mAbs used should be of murine origin. Development of such $m A b s$ requires immunization of gene-deficient mice with the autologous target protein.

Generation of mAbs against murine proteases using genedeficient mice was first described by Declerck et al. (1995a). Mice lacking the gene encoding either of the two main plasminogen activators, i.e., tissue-type plasminogen activator (tPA) and urokinase plasminogen activator (uPA), were immunized with murine tPA $(\mathrm{mtPA})$ and $\mathrm{muPA}$, respectively. Sera from the immunized mice had high titers of anti-mtPA and anti-muPA antibodies, while similar immunizations of wild-type mice resulted in no or little reactivity toward $\mathrm{mtPA}$ and $\mathrm{muPA}$, consistent with these proteins being self-antigens in wild-type mice (Opdenakker et al., 2003).

In this review, the properties of mouse mAbs, all generated by use of gene-deficient mice, will be described with respect to specificity, epitope location, cross-reactivity with the homologous protein from other species (conserved epitopes), and inhibitory function in vitro and in vivo. The antibody-mediated in vivo effect will be compared with that observed in gene-deficient mice to reveal similarities or changes between acute disruption of function in the adult animal and genetic disruption in utero.

\section{MONOCLONAL ANTIBODIES AGAINST MURINE PLASMINOGEN ACTIVATORS}

To generate mAbs against $\mathrm{mtPA}$, mice were immunized twice and subsequently boosted with $10 \mu \mathrm{g}$ recombinant $\mathrm{mtPA}$ before spleen cell isolation and fusion to myeloma cells. Hybridomas were selected for their ability to secrete antibodies reacting with $\mathrm{mtPA}$ using ELISA, resulting in the isolation of 203 hybridomas from two fusions. The amount of coating antigen in the ELISA was rather high (200 ng mtPA/well), allowing antibodies with relatively low 
affinity to be isolated. Of the $203 \mathrm{mAbs}, 21$ were selective for mouse $\mathrm{tPA}$, while the residual mAbs cross-reacted with $\mathrm{tPA}$ from one or more species, i.e., rat, human, and vampire-bat tPA. Importantly, no anti-mtPA mAbs recognized muPA (Declerck et al., 1995a).

The mAbs were also assayed for their inhibitory effect on the ability of tPA to activate plasminogen (Figure 1). Interestingly, it was demonstrated that of the $21 \mathrm{mAbs}$ recognizing epitopes specific for mtPA, six were inhibitory, whereas 105 of the 182 crossreacting mAbs were inhibitory (Declerck et al., 1995a). Hence, based on the apparent correlation between inhibitory properties and cross-reactivity, it was suggested that epitopes conserved between species are functionally important for plasminogen activation (Declerck et al., 1995a). Two of the anti-mtPA mAbs were used for design of a quantitative ELISA, enabling measurements of mtPA in tissue and body fluids from mice (Declerck et al., 1995b).

Using the same overall strategy, $\mathrm{uPA}^{-/-}$mice were immunized with muPA, resulting in 38 hybridomas producing antibodies against muPA (Declerck et al., 1995a). Specificity test showed negative reaction with $\mathrm{mtPA}$ for all of these antibodies and interestingly, none of the anti-muPA mAbs cross-reacted with human uPA (Declerck et al., 1995a). A quantitative ELISA was designed using two of the anti-muPA mAbs (Declerck et al., 1995b). Due to the low affinity of these anti-muPA mAbs, the sensitivity of this assay was 10 -fold lower than that of $\mathrm{mtPA}$, precluding measurements of muPA in plasma.

In a study with the aim to generate high affinity anti-muPA mAbs with in vivo efficacy, $\mathrm{uPA}^{-/-}$mice were immunized six times, followed by three boosting injections with recombinant promuPA (Lund et al., 2008). To ensure isolation of high affinity mAbs, the wells were coated with low amounts of antigen ( $2 \mathrm{ng}$ promuPA/well) in the hybridoma screening ELISA, resulting in identification of nine anti-muPA mAb secreting hybridomas. Especially, two mAbs ( $\mathrm{mU} 1$ and $\mathrm{mU} 3$ ), possessing epitopes in the uPA Bchain, encompassing the catalytic site, were demonstrated to interfere with the function of mouse uPA. Specificity test demonstrated no cross-reactivity with mouse tPA, and interestingly neither

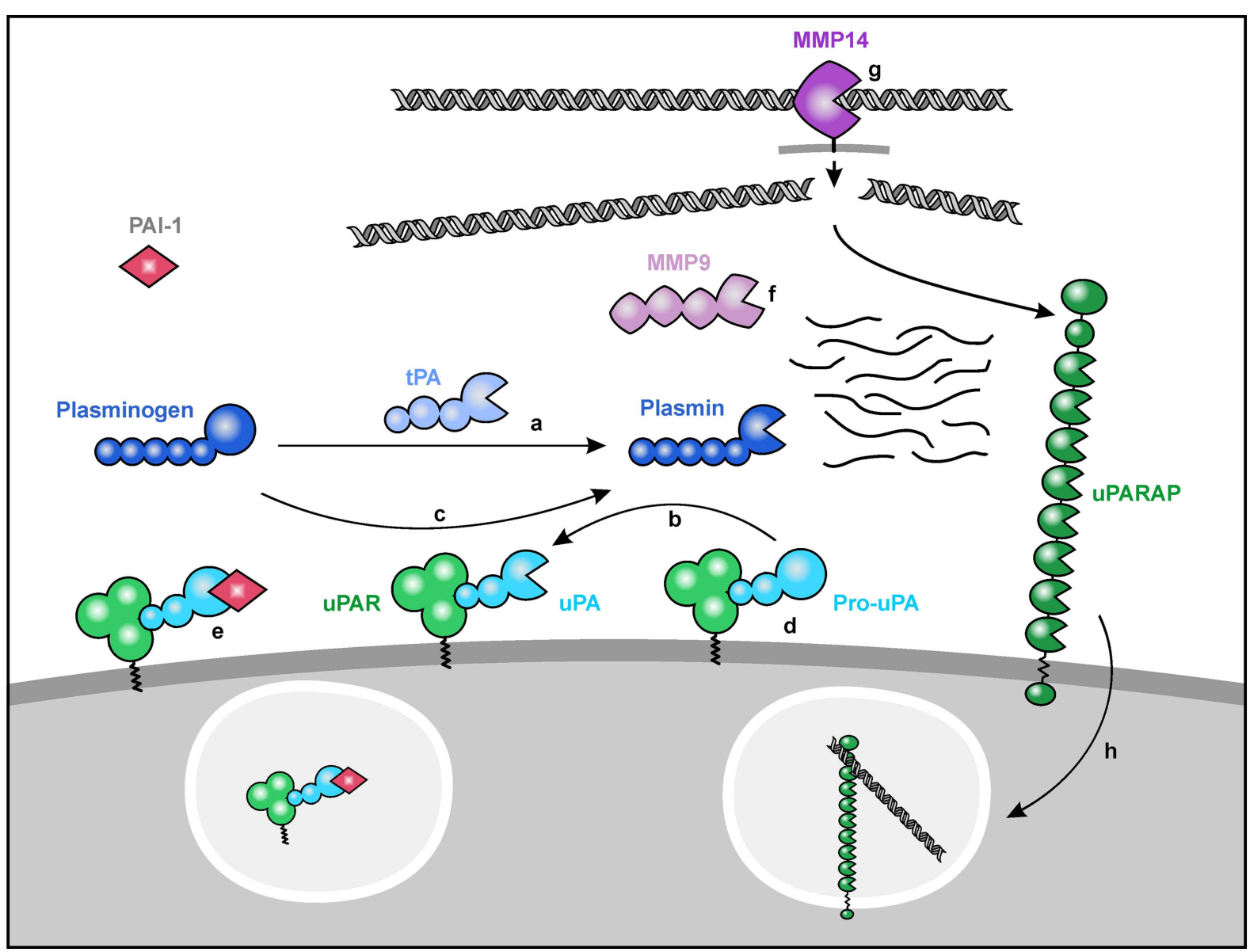

FIGURE 1 | Pathways of the plasminogen activation and MMP systems targeted by mouse $\mathrm{mAbs}$ blocking the functions of the proteases and receptors. Degradation of various components of the extracellular matrix involves both plasmin-mediated breakdown and degradation by MMPs, such as MMP9 and MMP14/MT1-MMP. This degradation of the extracellular matrix is a prerequisite for tissue remodeling, which takes place during cancer invasion. mAbs have been developed in order to target the functions of the proteases and receptors, indicated by (a-h). tPA (a) and UPA (c) can activate plasminogen to plasmin, which in turn mediates activation of pro-uPA to UPA (b), when pro-uPA is bound to its receptor UPAR (d) at the cell surface. Both UPA and TPA are inhibited by PAI-1 (e). MMP9 (f) and MMP14 (g) primarily degrade collagen in the extracellular matrix. Collagen and cleaved fragments hereof can bind to UPARAP and are subsequently internalized with the receptor (h). 
antibody recognized human uPA. Both $\mathrm{mU} 1$ and $\mathrm{mU} 3$ are high affinity antibodies. mU3 displays higher affinity for both pro$\operatorname{muPA}\left(K_{\mathrm{D}}=0.03 \mathrm{nM}\right)$ and muPA $\left(K_{\mathrm{D}}=0.2 \mathrm{nM}\right)$, as compared to mU1 [pro-muPA $\left(K_{\mathrm{D}}=0.2 \mathrm{nM}\right)$ and muPA $\left(K_{\mathrm{D}}=1.3 \mathrm{nM}\right)$ ]. These antibodies efficiently and dose-dependently block uPAmediated plasminogen activation. $\mathrm{mU} 1$ prevents both plasminmediated pro-uPA activation and uPA-mediated plasminogen activation (Figure 1), while mU3 only inhibits the latter of these reactions.

To test the effect of these mAbs in vitro in a multicomponent system, a cellular assay using uPA-activatable anthrax pro-toxin (Liu et al., 2001) was employed. In this assay, a cytotoxic effect is released as a result of cell-bound uPA activity, which serves to cleave an engineered protective antigen, PrAg-U2. Pre-incubation of murine monocyte macrophage-like P388D.1 cells with either mU1 or mU3 led to significant rescue of cells simultaneously exposed to PrAg-U2 and the recombinant toxin FP59 (Lund et al., 2008). Interestingly, the rescue effect of mU1 was stronger than that of $\mathrm{mU} 3$ in vitro. As $\mathrm{uPA}^{-1-}$ mice are insensitive to anthrax pro-toxin treatment (Liu et al., 2003), this system was used to determine the in vivo efficacy of $\mathrm{mU} 1$ and $\mathrm{mU} 3$ in wild-type mice. Two injections of the mAbs $(60 \mathrm{mg} / \mathrm{kg} /$ dose $)$ were administered to the mice prior to anthrax pro-toxin treatment. Of the wild-type mice treated with $\mathrm{mU} 1$, eight out of 10 mice survived, whereas only few mice treated with either mU3 or the isotype-matched negative control $\mathrm{mAb}$ survived, demonstrating $\mathrm{mU} 1$, but not $\mathrm{mU} 3$, to possess in vivo efficacy by blocking uPA activity (Figure 2; Lund et al., 2008, 2011a).

\section{MONOCLONAL ANTIBODIES AGAINST MUPAR}

The main function of the uPA receptor (UPAR), is to localize the proteolytic activity to the cell surface (Ellis and Danø, 1991). uPAR also interacts with vitronectin and various integrins, thereby possessing several biological functions independent of its role in uPA-mediated proteolysis (Høyer-Hansen and Lund, 2007; Smith and Marshall, 2010). Despite the multifunctional properties, $\mathrm{uPAR}^{-1-}$ mice show no overt phenotype (Bugge et al., 1995). To develop mAbs against muPAR, $\mathrm{uPAR}^{-/-}$mice were immunized with recombinant soluble muPAR (Pass et al., 2007). The procedures to generate hybridomas were identical to those described for the muPA mAbs (Pass et al., 2007; Lund et al., 2008). One fusion resulted in 12 hybridomas, secreting antibodies reacting with muPAR, including six that cross-reacted with human UPAR in Western blotting.

UPAR consist of three domains and the integrity of this structure is a prerequisite for the high affinity binding of uPA and of vitronectin (Behrendt et al., 1996; Høyer-Hansen et al., 1997). The epitopes of the anti-muPAR mAbs $\mathrm{mR} 1$ and $\mathrm{mR} 3$ are located on the N-terminal muPAR domain I, while those of mR2 and mR4 are situated on muPAR domains II-III (Pass et al., 2007; Rasch et al., 2008). They are all high affinity mAbs, with mR3 having the highest affinity $\left(K_{\mathrm{D}}=0.5 \mathrm{nM}\right) . \mathrm{mR} 1, \mathrm{mR} 2$, and $\mathrm{mR} 4$ cross-react with human UPAR and have similar affinities for UPAR from the two species (Rasch et al., 2008). mR1, mR2, and mR4 were all capable of blocking binding of the murine amino-terminal fragment of muPA (mATF) to muPAR (Figure 1; Pass et al., 2007; Rasch et al., 2008). mR1 and mR4 showed a dose-dependent inhibition of
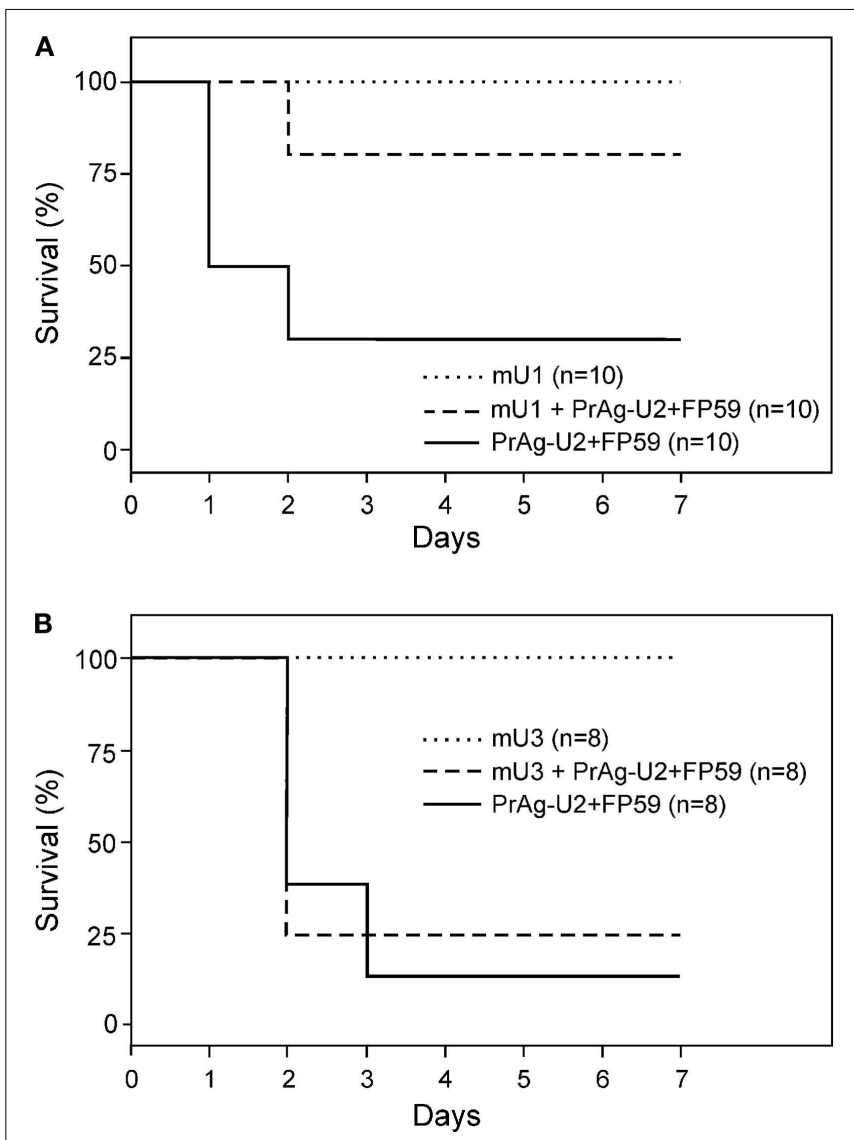

FIGURE 2 | mU1-induced rescue of adult mice treated with a uPA-activatable anthrax pro-toxin. (A) FVB/n wild-type mice received intraperitoneal injections of $60 \mathrm{mg} / \mathrm{kg} \mathrm{mU1}$ (dotted and broken lines) or an equivalent volume of saline (solid line; day -1 and 0 ), followed by injections with the uPA-activatable anthrax pro-toxin (i.e., $0.6 \mathrm{mg} / \mathrm{kg} \mathrm{PrAg}-\mathrm{U} 2+$ $0.4 \mathrm{mg} / \mathrm{kg}$ FP59; broken and solid lines) or saline alone (dotted line; day 0). Survival of the mice, presented in percentage, was recorded for 7 days. (B) $\mathrm{FVB} / \mathrm{n}$ wild-type mice were treated with $60 \mathrm{mg} / \mathrm{kg} \mathrm{mU3}$ (dotted and broken lines) or an equivalent volume of saline (solid line), and subsequently by $0.6 \mathrm{mg} / \mathrm{kg}$ PrAg-U2 + $0.4 \mathrm{mg} / \mathrm{kg}$ FP59 (broken and solid lines) or saline alone (dotted line), as described in A (Lund et al., 2008).

mATF binding with $\mathrm{IC}_{50}$ values of 0.67 and $0.34 \mathrm{nM}$, respectively, being similar to that of the biological ligand $\left(\mathrm{IC}_{50}=0.14 \mathrm{nM}\right)$. Intriguingly, mR3 did not interfere with the uPA-uPAR interaction, even though the complete epitope of mR1 (Gårdsvoll et al., 2011 ) is close to or overlapping with that of $\mathrm{mR} 3$, as these $\mathrm{mAbs}$ are unable to bind simultaneously to muPAR (Rasch et al., 2008). The binding site for vitronectin on UPAR is different from that for uPA (Wei et al., 1994). Some mAbs with epitopes in domain I of human uPAR block the binding of vitronectin (Høyer-Hansen et al., 1997), while none of the so far characterized mAbs, reacting with mouse uPAR domain I, prevents this interaction (Rasch et al., 2008).

The anti-muPAR mAbs were tested in rescue experiments using the above-described uPA-activatable anthrax pro-toxin assay (Pass et al., 2007). The experiments were performed both in vitro and in vivo in mice. Pre-incubation of uPAR-positive P388D.1 cells 
with $\mathrm{mR} 1$ resulted in significant cell rescue. For the same system in vivo, it was previously demonstrated that $\mathrm{uPAR}^{-1-}$ mice are insensitive to treatment with the toxins, providing evidence for the stringent need for receptor-bound uPA to release the anthrax cytotoxic effect (Liu et al., 2003). Administration of the anthrax pro-toxin simultaneously with two injections of $\mathrm{mR} 1$ $(60 \mathrm{mg} / \mathrm{kg} / \mathrm{dose})$ to the wild-type mice, resulted in rescue of all eight mice. Only two of seven mice treated with saline or the negative control mAb survived, thus demonstrating in vivo efficacy of $\mathrm{mR} 1$ by blocking the uPA-uPAR binding (Pass et al., 2007).

\section{MONOCLONAL ANTIBODIES AGAINST mPAI-1}

PAI-1 is the primary endogenous inhibitor of both tPA and UPA. The first reported murine mAbs against mPAI-1 were generated using the same protocol as for the anti-mtPA mAbs (see above), except that the immunized mice were PAI- $1^{-1-}$ and mPAI-1 was the antigen (Carmeliet et al., 1993; Declerck et al., 1995b). Two fusions resulted in 64 anti-mPAI- $1 \mathrm{mAb}$-producing hybridomas and two mAbs were successfully employed for design of a quantitative immunoassay for measurement of mPAI- 1 in murine plasma.

In a recent study, the aim was to generate inhibitory antimPAI-1 mAbs reacting with the glycosylated form of mPAI-1 bound to vitronectin (Van De Craen et al., 2011). PAI-1 is secreted in an active but conformationally unstable form, which rapidly loses activity unless bound to vitronectin (Declerck et al., 1988). The desired anti-PAI-1 mAbs should therefore also inhibit PAI1 activity of the PAI-1-vitronectin complex. Such anti-mPAI-1 mAbs were developed as previously described (Declerck et al., $1995 b)$, though with an increase in antigen dose from 10 to $55 \mu \mathrm{g}$ /injection. One fusion yielded 21 hybridomas producing anti-mPAI-1 antibodies. Two mAbs were specific for mPAI-1, 19 cross-reacted with rat PAI-1, and 14 of these also recognized human PAI-1. Five of the anti-mPAI-1 mAbs, reacting with epitopes conserved between the three species, were found to neutralize PAI-1 activity, even in the presence of a 33-fold molar excess of mouse vitronectin. In this neutralization assay, the inhibitory effect of the mAbs was determined as the ability of mPAI-1 to inhibit mtPA activity in the absence and presence of the antibodies (Figure 1) (Declerck et al., 1995b; Van De Craen et al., 2011).

The in vivo efficacy of the five most inhibitory mAbs was tested in a thromboplastin-dependent mouse thromboembolism model, designed to demonstrate the potential function of the mAbs to rescue injected mtPA from mPAI-1-mediated inactivation. Mice were injected with $10 \mathrm{mg} / \mathrm{kg}$ of the $\mathrm{mAb}$ via the tail vein. Thromboplastin was injected simultaneously with mtPA to evoke thromboembolism. A reduced physical activity was used as the read-out for the thromboembolic condition. Evaluation $15 \mathrm{~min}$. after treatment, demonstrated all five inhibitory anti-mPAI-1 mAbs to possess in vivo efficacy, as the mAb-treated mice were more active than control mice (Van De Craen et al., 2011). Two of these anti-mPAI$1 \mathrm{mAbs}$ have furthermore been demonstrated to decrease the level of active mPAI- 1 in mouse plasma, collected from mice treated with lipopolysaccharide to induce high mPAI-1 levels in the blood (Van De Craen et al., 2012).

\section{MONOCLONAL ANTIBODIES AGAINST mMMPs mMMPg}

Matrix metalloproteinase 9 (MMP9) belongs to the subfamily of gelatinases and is active in degradation of various components in the extracellular matrix, including early collagen cleavage fragments. Anti-mMMP9 mAbs have been generated by immunization of $\mathrm{MMP9}^{-/-}$mice with recombinant mMMP9 (Descamps et al., 2002; Opdenakker et al., 2003; Kolaczkowska et al., 2008). Hybridomas were identified by ELISA, in which the wells were coated with goat-anti-mouse IgG. Addition of hybridoma supernatants, followed by biotinylated mMMP9 was used to identify anti-mMMP9 producing clones. Of the 250 hybridomas secreting anti-mMMP9 antibodies, the 16 with the strongest reactions were selected (Kolaczkowska et al., 2008). Four of these mAbs were specific for the pro-form of mMMP9, two were specific for the active form, and the 10 remaining reacted with pro-mMMP9 as well as one or more of three degradation products (Kolaczkowska et al., 2008). The mAbs reacting exclusively with the active form were found to have MMP9 neutralizing activity (Figure 1), as measured using a fluorogenic substrate (Opdenakker et al., 2003).

\section{mMMP14/mMT1-MMP}

All of the above-mentioned gene-deficient mice have very mild, if at all comprised phenotypes and a normal life span (Carmeliet et al., 1993, 1994, 1995; Bugge et al., 1995; Vu et al., 1998). The MMP14 ${ }^{-1-}$ mice have in contrast a severe phenotype and a short life span (7-13 weeks) as they develop craniofacial dysmorphism, arthritis, osteopenia, dwarfism, and fibrosis of soft tissues due to inadequate collagen turn-over (Holmbeck et al., 1999). To enable generation of anti-mMMP14 mAbs, immunizations were therefore initiated 4 weeks after birth of the $\mathrm{MMP}^{-1-}$ mice, as compared with the usual age of 8-9 weeks. The mice were only immunized twice, followed by three boosting injections with $15 \mu \mathrm{g}$ recombinant soluble mMMP14 (Ingvarsen et al., 2008). Due to the small size of their spleens, splenocytes isolated from five immunized MMP $14^{-1-}$ mice were pooled for one fusion. Screening for hybridomas was performed using ELISA with each well coated with $12 \mathrm{ng}$ mMMP14. Six hybridomas secreting anti-mMMP14 antibodies were isolated. The epitopes are located in the hemopexin domain and/or in the membrane-proximal linker region of mMMP14. The mAbs cross-react with the human form of MMP14. Interestingly, one $\mathrm{mAb}$ is capable of stimulating the MMP14 dimerization step on the cell surface, which is necessary for MMP14-mediated activation of the soluble gelatinase, MMP2. None of the mAbs possess any inhibitory effect on the collagenolytic activity of mMMP14 (Figure 1; Ingvarsen et al., 2008).

\section{MONOCLONAL ANTIBODIES AGAINST UPARAP/END0180}

UPARAP (also designated Endo180), a member of the mannose receptor family, is a collagen internalization receptor and a type 1 transmembrane protein (Behrendt, 2004; Engelholm et al., 2009). For the generation of mAbs, $\mathrm{uPARAP}^{-/-}$mice were immunized with recombinant soluble human uPARAP (Sulek et al., 2007). All procedures were identical to those described for generation of mAbs against muPA and muPAR (Pass et al., 2007; Lund et al., 2008). Interestingly, seven out of eight mAbs cross-react with 
mouse uPARAP. The anti-uPARAP mAb $5 \mathrm{f} 4$ was demonstrated to inhibit cellular collagen internalization in fibroblasts (Figure 1; Madsen et al., 2011). Due to this mechanism of action, addition of $5 f 4$ to wild-type cultured fibroblasts leads to accumulation of collagen degradation products in the cell culture medium, being similar to the collagen fragments that occur in the medium of uPARAP $^{-1-}$ mouse fibroblasts, cultured without antibody addition (Jürgensen et al., 2011; Madsen et al., 2011). Although the epitope of $5 \mathrm{f} 4$ is located to the $\mathrm{N}$-terminal domains $1-3$ of uPARAP (Madsen et al., 2012), the antibody does not prevent binding of uPARAP to collagen in a purified system. The capacity of blocking collagen internalization may be related to another interesting characteristic as the antibody down-regulates uPARAP expression on the cell surface (Madsen et al., 2011).

\section{COMPARISON OF EFFECTS OF ACUTE DISRUPTION OF PROTEIN FUNCTION IN THE ADULT ANIMAL AND GENETIC DISRUPTION IN UTERO}

Studies with gene-deficient animals have demonstrated uPA to play an important role in skin wound healing and extravascular fibrin clearance in the liver as well as the presence of a strong redundancy between uPA and tPA (Bugge et al., 1996). Mice deficient in uPA or tPA have a marginal delay in wound healing, while $\mathrm{uPA}^{-1-} ; \mathrm{tPA}^{-1-}$ double-deficient mice display a significant delay compared to wild-type littermates (Lund et al., 2006). To study the effect of acute disruption of uPA function in wound healing, $\mathrm{tPA}^{-1-}$ mice were treated with $\mathrm{mU1}(60 \mathrm{mg} / \mathrm{kg})$, administered according to the $\mathrm{mAb}$ half-life (Jögi et al., 2010). Importantly, mU1 caused a delay in wound healing, resulting in a healing time, which was not significantly different from that of the $\mathrm{uPA}^{-1-} ; \mathrm{tPA}^{-1-}$ mice (Jögi et al., 2010). Consistent with uPA and tPA being the main plasminogen activators, a reduced level of plasmin was detected in wound extracts from mU1-treated $\mathrm{tPA}^{-1-}$ mice, and the plasmin level was similar to that in $\mathrm{uPA}^{-1-} ; \mathrm{tPA}^{-1-}$ mice. This underscores that administration of $\mathrm{mU} 1$ blocks plasminogen activation in vivo (Jögi et al., 2010).

Both $\mathrm{uPA}^{-1-} ; \mathrm{tPA}^{-1-}$ and $\mathrm{uPAR}^{-1-} ; \mathrm{tPA}^{-1-}$ mice spontaneously develop hepatic fibrin deposits (Bugge et al., 1996). While $\mathrm{uPA}^{-1-}$ mice occasionally display fibrin accumulation in the liver, no deposits have been detected in neither $\mathrm{tPA}^{-1-}$ nor $\mathrm{uPAR}^{-1-}$ mice (Bugge et al., 1996). Hence, to evaluate the effect of mU1 and $\mathrm{mR} 1$ on in vivo fibrin clearance, $\mathrm{tPA}^{-1-}$ mice were treated with either mAb (Jögi et al., 2007; Lund et al., 2008). Systemic treatment

\section{REFERENCES}

Behrendt, N. (2004). The urokinase receptor (UPAR) and the uPAR-associated protein (uPARAP/Endo180): membrane proteins engaged in matrix turnover during tissue remodeling. Biol. Chem. 385, 103-136.

Behrendt, N., Rønne, E., and Danø, K. (1996). Domain interplay in the urokinase receptor. Requirement for the third domain in high affinity ligand binding and demonstration of ligand contact sites in distinct receptor domains. J. Biol. Chem. 271, 22885-22894.

Bugge, T. H., Flick, M. J., Danton, M. J., Daugherty, C. C., Rømer, J., Danø, K., Carmeliet, P., Collen, D., and Degen, J. L. (1996). Urokinase-type plasminogen activator is effective in fibrin clearance in the absence of its receptor or tissue-type plasminogen activator. Proc. Natl. Acad. Sci. U.S.A 93, 5899-5904.

Bugge, T. H., Suh, T. T., Flick, M. J., Daugherty, C. C., Rømer, J., Solberg, H., Ellis, V., Danø, K., and Degen, J. L. (1995). The receptor for

with $\mathrm{mU} 1$ as well as with $\mathrm{mR} 1$ resulted in hepatic fibrin accumulation in $\mathrm{tPA}^{-1-}$ mice, being indistinguishable from the depositions observed in corresponding double-deficient mice (Jögi et al., 2007; Lund et al., 2008).

A recent study has demonstrated $\mathrm{uPARAP}^{-1-}$ mice to possess increased accumulation of both total fibrillar collagen and collagen type IV upon $\mathrm{CCl}_{4}$-induced liver fibrosis (Madsen et al., 2012). Hepatic collagen deposition in wild-type mice with liver fibrosis thus seems as a suitable model for testing the in vivo efficacy of the anti-uPARAP mAbs.

In addition to the overlapping roles between uPA and tPA in certain physiological processes, it was recently demonstrated that ablation of MMP9 in combination with either plasminogen activator impairs normal gestation, resulting in a non-Mendelian distribution of the off-spring (Lund et al., 2011b). Furthermore, combined deficiency in MMP9 and uPA, but not tPA, causes a significant delay in wound healing as compared to the single-deficient and wild-type littermate control mice. Notably, a compensatory upregulation of uPA activity is seen in wound extracts from MMP9 deficient mice (Lund et al., 2011b). Consequently, these systems are interesting for studies using the described mAbs against mouse uPA and MMP9, employing wild-type or the relevant single-deficient mice for treatment.

\section{CONCLUSION}

Monoclonal antibodies (mAbs) raised in gene-deficient mice have the unique ability to recognize epitopes conserved between species. Additional reactivity with species-specific epitopes provides a more diverse reactivity with the antigen than mAbs raised in wild-type mice. Furthermore, some studies have suggested crossreacting $\mathrm{mAbs}$ to be superior inhibitors to $\mathrm{mAbs}$ only reacting with species-specific epitopes. Compared to small molecular inhibitors, the mAbs possess an amazing selectivity, have a long half-life in circulation (3-6 days; Pass et al., 2007; Lund et al., 2008), and are therefore well-suited for therapy experiments in mouse models of different diseases, including cancer.

\section{ACKNOWLEDGMENTS}

We thank all the partners in Microenvimet for fruitful and inspiring discussions and collaborations. We thank John Post for graphic assistance. Much of the research leading to these results has received funding from the European Community's Seventh Framework Program FP7/2007-2011 under grant agreement $n^{\circ} 201279$.

urokinase-type plasminogen activator is not essential for mouse development or fertility. J. Biol. Chem. 270, 16886-16894.

Carmeliet, P., Bouche, A., De, C. C., Janssen, S., Pollefeyt, S., Wyns, S., Mulligan, R. C., and Collen, D. (1995). Biological effects of disruption of the tissue-type plasminogen activator, urokinase-type plasminogen activator, and plasminogen activator inhibitor-1 genes in mice. Ann N. Y. Acad. Sci. 748, 367-381.

Carmeliet, P., Kieckens, L., Schoonjans, L., Ream, B., van, N. A., Prendergast,
G., Cole, M., Bronson, R., Collen, D., and Mulligan, R. C. (1993). Plasminogen activator inhibitor-1 gene-deficient mice. I. Generation by homologous recombination and characterization. J. Clin. Invest. 92, 2746-2755.

Carmeliet, P., Schoonjans, L., Kieckens, L., Ream, B., Degen, J., Bronson, R., De, V. R., van den Oord, J. J., Collen, D., and Mulligan, R. C. (1994). Physiological consequences of loss of plasminogen activator gene function in mice. Nature 368, 419-424. 
Declerck, P. J., Carmeliet, P., Verstreken, M., De, C. F., and Collen, D. (1995a). Generation of monoclonal antibodies against autologous proteins in gene-inactivated mice. J. Biol. Chem. 270, 8397-8400.

Declerck, P. J., Verstreken, M., and Collen, D. (1995b). Immunoassay of murine t-PA, u-PA and PAI-1 using monoclonal antibodies raised in gene-inactivated mice. Thromb. Haemost. 74, 1305-1309.

Declerck, P. J., De, M. M., Alessi, M. C., Baudner, S., Paques, E. P., Preissner, K. T., Müller-Berghaus, G., and Collen, D. (1988). Purification and characterization of a plasminogen activator inhibitor 1 binding protein from human plasma. Identification as a multimeric form of $\mathrm{S}$ protein (vitronectin). J. Biol. Chem. 263, 15454-15461.

Descamps, F. J., Martens, E., and Opdenakker, G. (2002). Analysis of gelatinases in complex biological fluids and tissue extracts. Lab. Invest. 82, 1607-1608.

Ellis, V., and Danø, K. (1991). Plasminogen activation by receptor-bound urokinase. Semin. Thromb. Hemost. 17, 194-200.

Engelholm, L. H., Ingvarsen, S., Jürgensen, H. J., Hillig, T., Madsen, D. H., Nielsen, B. S., and Behrendt, N. (2009). The collagen receptor uPARAP/Endo180. Front. Biosci. 14, 2103-2114.

Gårdsvoll, H., Jacobsen, B., Kriegbaum, M. C., Behrendt, N., Engelholm, L., Østergaard, S., and Ploug, M. (2011). Conformational regulation of urokinase receptor function: impact of receptor occupancy and epitope-mapped monoclonal antibodies on lamellipodia induction. $J$. Biol. Chem. 286, 33544-33556.

Holmbeck, K., Bianco, P., Caterina, J., Yamada, S., Kromer, M., Kuznetsov, S. A., Mankani, M., Robey, P. G., Poole, A. R., Pidoux, I., Ward, J. M., and Birkedal-Hansen, H. (1999). MT1-MMP-deficient mice develop dwarfism, osteopenia, arthritis, and connective tissue disease due to inadequate collagen turnover. Cell 99, 81-92.

Høyer-Hansen, G., Behrendt, N., Ploug, M., Danø, K., and Preissner, K. T. (1997). The intact urokinase receptor is required for efficient vitronectin binding: receptor cleavage prevents ligand interaction. FEBS Lett. 420, 79-85.

Høyer-Hansen, G., and Lund, I. K. (2007). Urokinase receptor variants in tissue and body fluids. Adv. Clin. Chem. 44, 65-102.

Ingvarsen, S., Madsen, D. H., Hillig, T., Lund, L. R., Holmbeck, K., Behrendt, N., and Engelholm, L. H. (2008).
Dimerization of endogenous MT1MMP is a regulatory step in the activation of the $72-\mathrm{kDa}$ gelatinase MMP-2 on fibroblasts and fibrosarcoma cells. Biol. Chem. 389, 943-953.

Jögi, A., Pass, J., Høyer-Hansen, G., Lund, L. R., Nielsen, B. S., Danø, K., and Rømer, J. (2007). Systemic administration of anti-urokinase plasminogen activator receptor monoclonal antibodies induces hepatic fibrin deposition in tissuetype plasminogen activator deficient mice. J. Thromb. Haemost. 5, 1936-1944.

Jögi, A., Rønø, B., Lund, I. K., Nielsen, B. S., Ploug, M., HøyerHansen, G., Rømer, J., and Lund, L. R. (2010). Neutralisation of uPA with a monoclonal antibody reduces plasmin formation and delays skin wound healing in tPAdeficient mice. PLoS. One. 5, e12746. doi:10.1371/journal.pone.0012746

Jürgensen, H. J., Madsen, D. H., Ingvarsen, S., Melander, M. C., Gårdsvoll, H., Patthy, L., Engelholm, L. H., and Behrendt, N. (2011). A novel functional role of collagen glycosylation: interaction with the endocytic collagen receptor uparap/ENDO180. J. Biol. Chem. 286, 32736-32748.

Kolaczkowska, E., Arnold, B., and Opdenakker, G. (2008). Gelatinase B/MMP-9 as an inflammatory marker enzyme in mouse zymosan peritonitis: comparison of phasespecific and cell-specific production by mast cells, macrophages and neutrophils. Immunobiology 213, 109-124.

Liu, S., Aaronson, H., Mitola, D. J., Leppla, S. H., and Bugge, T. H. (2003). Potent antitumor activity of a urokinase-activated engineered anthrax toxin. Proc. Natl. Acad. Sci. U.S.A 100, 657-662.

Liu, S., Bugge, T. H., and Leppla, S. H. (2001). Targeting of tumor cells by cell surface urokinase plasminogen activator-dependent anthrax toxin. J. Biol. Chem. 276, 17976-17984.

Lund, I. K., Illemann, M., Thurison, T., Christensen, I. J., and HøyerHansen, G. (2011a). uPAR as anticancer target: evaluation of biomarker potential, histological localization, and antibody-based therapy. Curr. Drug Targets 12, 1744-1760.

Lund, I. K., Nielsen, B. S., Almholt, K., Rønø, B., Hald, A., Illemann, M., Green, K. A., Christensen, I. J., Rømer, J., and Lund, L. R. (2011b). Concomitant lack of MMP9 and uPA disturbs physiological tissue remodeling. Dev. Biol. 358, 56-67.

Lund, I. K., Jögi, A., Rønø, B., Rasch, M. G., Lund, L. R., Almholt, K.,
Gårdsvoll, H., Behrendt, N., Rømer, J., and Høyer-Hansen, G. (2008). Antibody-mediated targeting of the uPA proteolytic function neutralizes fibrinolysis in vivo. J. Biol. Chem. 283, 32506-32515.

Lund, L. R., Green, K. A., Stoop, A. A., Ploug, M., Almholt, K., Lilla, J., Nielsen, B. S., Christensen, I. J., Craik, C. S., Werb, Z., Danø, K. and Rømer, J. (2006). Plasminogen activation independent of uPA and TPA maintains wound healing in gene-deficient mice. EMBO J. 25 , 2686-2697.

Madsen, D. H., Ingvarsen, S., Jürgensen, H. J., Melander, M. C., Kjøller, L., Moyer, A., Honore, C., Madsen, C. A., Garred, P., Burgdorf, S., Bugge, T. H., Behrendt, N., and Engelholm, L. H. (2011). The non-phagocytic route of collagen uptake: a distinct degradation pathway. J. Biol. Chem. 286, 26996-27010.

Madsen, D. H., Jürgensen, H. J., Ingvarsen, S., Melander, M. C., Vainer, B., Egerod, K. L., Hald, A., Rønø, B., Madsen, C. A., Bugge, T. H. Engelholm, L. H., and Behrendt, N. (2012). Endocytic collagen degradation: a novel mechanism involved in the protection against liver fibrosis. J. Pathol. 227, 94-105.

Opdenakker, G., Van Den Steen, P. E., Laureys, G., Hunninck, K., and Arnold, B. (2003). Neutralizing antibodies in gene-defective hosts. Trends Immunol. 24, 94-100.

Page-McCaw, A., Ewald, A. J., and Werb, Z. (2007). Matrix metalloproteinases and the regulation of tissue remodelling. Nat. Rev. Mol. Cell Biol. 8, 221-233.

Pass, J., Jögi, A., Lund, I. K., Rønø, B., Rasch, M. G., Gårdsvoll, H., Lund, L. R.,Ploug, M., Rømer,J., Danø, K., and Høyer-Hansen, G. (2007). Murine monoclonal antibodies against murine uPA receptor produced in gene-deficient mice: inhibitory effects on receptor-mediated uPA activity in vitro and in vivo. Thromb. Haemost. 97,1013-1022.

Rasch, M. G., Pass, J., Illemann, M., Høyer-Hansen, G., and Lund, I. K. (2008). Discrimination of different forms of the murine urokinase plasminogen activator receptor on the cell surface using monoclonal antibodies. J. Immunol. Methods 339, 55-65.

Smith, H. W., and Marshall, C. J. (2010). Regulation of cell signalling by uPAR. Nat. Rev. Mol. Cell Biol. 11, 23-36.

Stevens, L. J., and Page-McCaw, A. (2012). A secreted MMP is required for reepithelialization during wound healing. Mol. Biol. Cell 23 , 1068-1079.
Sulek, J., Wagenaar-Miller, R. A., Shireman, J., Molinolo, A., Madsen, D. H., Engelholm, L. H., Behrendt, N., and Bugge, T. H. (2007). Increased expression of the collagen internalization receptor uPARAP/Endo180 in the stroma of head and neck cancer. J. Histochem. Cytochem. 55, 347-353.

Van De Craen, B., Scroyen, I., Abdelnabi, R., Brouwers, E., Lijnen, H. R., Declerck, P. J., and Gils, A. (2011). Characterization of a panel of monoclonal antibodies toward mouse PAI-1 that exert a significant profibrinolytic effect in vivo. Thromb. Res. 128, 68-76.

Van De Craen, B., Scroyen, I., Vranckx, C., Compernolle, G., Lijnen, H. R., Declerck, P. J., and Gils, A. (2012). Maximal PAI-1 inhibition in vivo requires neutralizing antibodies that recognize and inhibit glycosylated PAI-1. Thromb. Res. 129, e126-e133.

Vu, T. H., Shipley, J. M., Bergers, G., Berger, J. E., Helms, J. A., Hanahan, D., Shapiro, S. D., Senior, R. M., and Werb, Z. (1998). MMP9/gelatinase $B$ is a key regulator of growth plate angiogenesis and apoptosis of hypertrophic chondrocytes. Cell 93, 411-422.

Wei, Y., Waltz, D. A., Rao, N., Drummond, R. J., Rosenberg, S., and Chapman, H. A. (1994). Identification of the urokinase receptor as an adhesion receptor for vitronectin. $J$. Biol. Chem. 269, 32380-32388.

Conflict of Interest Statement: The authors declare that the research was conducted in the absence of any commercial or financial relationships that could be construed as a potential conflict of interest.

Received: 03 April 2012; accepted: 07 June 2012; published online: 28 June 2012.

Citation: Lund IK, Rasch MG, Ingvarsen S, Pass J, Madsen DH, Engelholm $L H$, Behrendt $N$ and Høyer-Hansen $G$ (2012) Inhibitory monoclonal antibodies against mouse proteases raised in genedeficient mice block proteolytic functions in vivo. Front. Pharmacol. 3:122. doi: 10.3389/fphar.2012.00122

This article was submitted to Frontiers in Pharmacology of Anti-Cancer Drugs, a specialty of Frontiers in Pharmacology. Copyright (c) 2012 Lund, Rasch, Ingvarsen, Pass, Madsen, Engelholm, Behrendt and Høyer-Hansen. This is an open-access article distributed under the terms of the Creative Commons Attribution Non Commercial License, which permits non-commercial use, distribution, and reproduction in other forums, provided the original authors and source are credited. 